\title{
Program Evaluation of Continuing Professional Development at Teacher Working Group
}

\author{
Zainuddin ${ }^{1, a}$, Suryadi1,b, Nurhatati Fuad ${ }^{1, c}$ \\ 1Department of Education Management, Universitas Negeri Jakarta, Jakarta Timur, 13220, Indonesia \\ a udinsiata@gmail.com; b hcsuryadi.unj@gmail.com; c nurhatati@gmail.com \\ *Corresponding Author
}

How to Cite : Zainuddin, Z., Suryadi, S., Fuad, N. (2019). Program Evaluation of Continuing Professional Development at Teacher Working Group. International Journal for Educational and Vocational Studies, 1 (2), 130-137.

\section{ARTICLE HISTORY}

Received:3 April 2019

Revised: 18 May2019

Accepted: 13 June 2019

\section{KEYWORDS}

Continuing Professional Development; Teacher Working;

Group Education;

\begin{abstract}
The aims of the study is to evaluate implemention of the continuing professional development program in Teacher Working Group at antecedent, transaction, and outcomes levels. The paper is an qualitative studi with Stkaes' contienance evaluation model and contiuned in Teacher Working Group at Nort Jakarta City. The data were collected through participant observation using interviewobservation document study and questionare. The result of the study showed that at the antecedent level there was stell lack of suffort from ical government such as prowding recource persons gudance and finding at transaction level at the showed that the planning and implementation of continuing professional development was not based on the needs of teacher competences and carier and there was no feed back an in continuing and the evaluation of the outcomes level the product of continuing professional development has not been used for upgrading Teachers cariers. The conclusion of the study was that the implementation of the continuing professional development program in Teacher Working Group is less effective and efficien the lock at the local government support to the program icads to an overall in effective and in efficient planning progress, monitoring and evaluation program Allthought the outcomes from the program effech the result of performance appraisal and students achievment it didnot contribute to competencies and carier upgrading, itis recomemded that the local government needs. to improve teachers management and support the program especially in improving techers capital in comprehensive and strategic ways.
\end{abstract}

This is an open access article under the CC-BY-SA license.

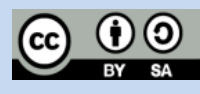

\section{INTRODUCTION}

One of the teacher's obligations is to improve and develop academic qualifications and competencies on an ongoing basis in line with the development of science, technology and art and in carrying out their duties in accordance with their positions and levels, teachers must carry out the main activity elements, namely education, learning/ guidance and additional assignments and/or other tasks relevant to the function of the school/madrasah; and continuous professional development, and following activities that support the implementation of teacher duties.

In several international literature studies including, Jones in Babita Arora (2016:295), Villegas-Reimers in Yumiko and Johanna (2010:29), A. Whohab Khan et al (2010:01), Minae I. Mwangi, and David Khatete (2016:250), shows that teachers as human resources are pioneers in building Indonesian human beings and teacher professional development as one of the key eleme- nts in most ongoing educational reforms in the world.

In the framework of human capital in human resources in the field of education, based on the State Ministry of State Apparatus and Reform and Bureaucracy Regulation Number 16 of 2009 concerning Teacher's Functional Position and and Credit Figures. Article 1, the teacher is a functional position that has scope, duties, responsibilities, and authority to carry out activities to educate, teach, guide, direct, train, assess, and evaluate students in early childhood education in formal education, basic education, and secondary education in accordance with the laws and regulations occupied by Civil Servants, one of the obligations of the teacher is to improve and develop academic qualifications and competencies on an ongoing basis in line with the development of science, technology and art and in carrying out their duties in accordance with their positions and levels. the teacher is obliged to carry out the main activity element, namely following education, learning/guidance and additional 
assignments and/or other tasks relevant to the function of the school/madrasah; and continuous professional development, as well as participating in activities that support the implementation of Teacher's duties.

In line with the implementation concerning that teachers are obliged to improve competency on an ongoing basis as part of Sustainable Professional Development, it is necessary to empower Teacher Working Groups (KKG) as a forum for activities or meetings for very strategic teacher to improve teacher competence and teacher performance.

Based on data from the Ministry of Education and Culture, Directorate General of Teachers and Education Personnel, Master Data on Primary Education Level 2017, the number of primary school teachers in Indonesia is 1 . 512.642 and there are $27.26 \%$ of teachers who do not have S1/DIVacademic qualifications. 2013 Education Personnel Educators' Unique Number Data (NUPTK) in Indonesia is $3,015,315$ and there are $28.2 \%$ of teachers who do not have S1/DIV academic qualifications. Furthermore, the initial competency test in 2012 to map the teacher's knowledge of pedagogics and professionals (subjects possessed) to 281,019 certified teachers showed that the national average was 42.25 with the lowest score of 1.0 and the highest score of 97.0. While the results of the 2013 teacher competency test show that the national average is 47.84 with the lowest value of 1.0 and the highest value of 100.0. The results of the competency test show that teacher competency is still low, especially in pedagogical, social, and professional competencies. While the results of the 2015 teacher competency test, out of $1,389,859$ the number of elementary school teachers showed that the average pedagogical competency was 48.75 and professional competence was 56.72, combined 54.33. Law Number 14 of 2005 concerning Teachers and Lecturers, Article 8 - Article 10, in carrying out their professional duties, the teacher is obliged to improve and develop academic qualifications and competencies on an ongoing basis in line with the development of science, technology and art.

Diah Widuri (2013:2302), Al Yahya, Mohammed Saad and Norsiah (2011:14) in their research explaining that teacher working group (KKG) empowerment is considered to be done immediately as an effort to improve teacher performance, among others, through instructor training, improving facilities and infrastructure, and improving the quality of KKG management. As for the KKG specifically, to date there have been several KKG that have not made a significant contribution to improving teacher competency and performance because: (1) the KKG needs to be improved in an effort to optimize the intensification of coaching in the KKG; (2) Programs for KKG activities that are not in accordance with the professional development needs of teachers, principals and school supervisors and (3) Operational support funds are inadequate and not properly utilized. In addition, according to the Teaching and Learning International Survey (TLIS) conducted by the Organization for
Economic Co-operation and Development (OECD) (2009) states that: "a significant proportion of teachers think that professional development does not meet their needs". It means that teacher professional development activities available do not meet the needs of teachers in the field.

With regard to the above, the Ministry of Education and Culture of the Directorate General of Quality Improvement of Educators and Education Personnel develops guidelines for the implementation of the KKG as a reference for teachers and administrators of KKG in conducting work group activities, so that activities carried out can be more directed and can be used as a vehicle for development quality, independent and sustainable teacher professionalism.

One of the reasons for the low teacher competency is that teacher professional development has not been optimal. Teacher professional development activities organized by the Ministry of Education and Culture do not include all teachers throughout Indonesia. With the existence of various limitations and constraints, both in terms of resources and geographical conditions, teacher professional activities need to be held as close and affordable to the teacher. Therefore working groups are very important organizations as a forum for teacher activities in developing teacher competencies and professionalism. In a number of observations, he explained that these working groups could be adjusted to the needs of the members' teachers. However, nowadays, teacher working groups have not been well implemented the learning process in the working group has not been well implemented, the learning process in the working group tends to be passive and centered on the guide, the KKG activity program has revealed and fulfilled the teacher's needs, but the implementation it has not been implemented in accordance with expectations, the level of discipline of teachers in participating in work groups has not shown seriousness of seriousness, this can be seen the level of attendance and arrival of teachers who are not on time.

Considering the obligation of teachers to participate in Continuing Professional Development activities as part of developing their competencies and careers as well as the vital self-development activities of teachers at the KKG in increasing their knowledge, competency and skills in carrying out their main tasks, there is a need to conduct studies evaluating continuous professional development programs for teachers in KKG in an effort to increase education human resources as human capital.

\section{LITERATURE REVIEW}

\subsection{Concept of Program Evaluation}

Activities to evaluate and measure the success of a program are known as program evaluations. There are several definitions of evaluation known as program evaluation. There are several definitions of evaluation 
proposed by experts, including. Goodall, Janet, Cristoper Day (2005) states that evaluation includes steps to determine and describe the accuracy of the evaluation process, data analysis and disseminating results by ensuring that evaluations are useful for stakeholders.

According to Alkin, Marvin C., (2011) explains that: "evaluation is judging the merit or worth of an entity". It means that evaluation is assessing the benefits or content of a project, evaluation is more oriented to decision making. According to Tyler quoted by Arikunto and Safrudin, (2010) program evaluation is a process to find out whether educational goals can be realized.

\subsection{Continuous Professional Development Program}

The sustainable development program is one program that supports teachers in carrying out their duties of improving and developing academic qualifications and competition in a sustainable manner in line with the development of science, technology and art. According to Day in Goodall, (2005) continuous professional development is all learning experiences and activities carried out consciously and planned and has benefits directly or indirectly to individuals, groups or schools to improve the quality of education in the classroom. According to Hammond in Evans, (2015) continuous professional profession of teachers is a process in enhancing the status of teacher professionalism through the development of competencies related to his profession and increasing awareness of his knowledge.

Whereas Kennedy, (2005:31) describes nine sustainable Koprofesian development models, namely: (1) Training, focusing on skills provided by experts with little practice; (2) Bearing awards, are intermediaries of tertiary education with conditions in the field; 3) Deficit, to meet the shortcomings of each individual teacher; 4) Cascade, training carried out through the dissemination of one of the teachers in the school; (4) Standard based, training based on established standards; (5) Coaching/ mentoring, coaching/mentoring development with work colleagues; 6) Community of practice, training through work groups; (7) Action research, learning by conducting pre-arranged teaching practices; (8) Transformative, integration of several different types of models with high awareness and supervision in their implementation.

Lieberman in Jo Rose and David Reynolds (2007) classifies continuous professional development into three types, namely direct teaching such as courses, workshops, etc .; learning in schools, such as peer coaching, critical friendships, mentoring, classroom action research and the field planning team; and learning outside of school, such as learning networks, study visits in collaboration with schools and universities, and so on.

\subsection{Teacher Working Group (KKG)}

Based on the explanation of Government Regulation number 74 of 2008 Article 47 paragraph 4, the development and improvement of competencies for
Teachers is carried out in various professionalism activities held among others through the Teacher Working Group (KKG), MGMP, School Supervisor Working Groups (KPPS ), and School Supervisory Working Meeting (MKPS). The Teacher Working Group (KKG) is a forum for professional activities for SD / MI / SDLB Teachers at the sub-district level consisting of a number of teachers from a number of schools. Whereas MGMP is a forum for professional activities for the same subject teachers at the SMP / MTs / SMPLB, SMA / MA / SMALB, and Vocational / MAK levels at the district / city level consisting of a number of schools.

The GFC has grown from year to year. The formation of the KKG as one of the first professional educational institutions in 1993 through the Primary Education Quality Improvement Project (PEQIP) is a collaborative project between the Ministry of National Education and the World Bank. Through the PEQIP Project, the establishment of the GFC was implemented through Decree of the Director General of Education and Culture No. 070 / C / kep / 1/93 dated 7 April 1993. Increased learning outcomes through education reform can be realized through the KKG. The trick is to absorb as much information as possible about educational reform formats and strategies which can then be applied or practiced in their respective schools.

\section{METHODS}

This study uses a qualitative approach to program evaluation methods, contenance stake models, in the form of antecedents, transactions and outcomes, data collection through questionnaires, structured interviews and document studies. Number of respondents 957 teachers. Data validity checking technique through data source triangulation, namely regional level service units, chair of teacher working groups, teachers, principals, and school supervisors, as well as triangulation of methods, namely observation, interviews, and questionnaires. The procedure of data analysis in this study is through categorization of data from questionnaires, interviews, and observations based on the components and aspects evaluated.

\section{RESULTS AND DISCUSSION}

\subsection{Results}

The results of research on the Continuing Professional Development Program in the Teacher Working Group in East Jakarta City are based on antecedents, transactions, and outcomes stages.

\subsubsection{Antecedents}

At the antecedents stage, Unique Number of Educator and Education Personnel data in 2016. It shows that 
around 25, 91\% of Elementary School teachers in MakasarSubdistrict, East Jakarta City do not have Academic qualifications for Bachelor / Diploma IV is 395 teachers from 975 teachers or 25.91\% . Teachers who do not have Academic qualifications for Bachelor / Diploma IV are $84.81 \%$ with status not Civil Servants and 15, 18\% with the status of Civil Servants. Civil Servant Primary School Teachers in MakasarSubdistrict, East Jakarta City who already have educator certificates are $60.6 \%$ while non-Civil Servants who already have educator certificates are $34 \%$. School supervisors as coaches of the Teacher Working Group in the District of Makasar, East Jakarta City, have had an academic qualification for a Master to obtain a professional certificate. Understanding the basic concepts and objectives of Sustainable Professional Development has been understood by the technical implementation unit of the MakasarSubdistrict in East Jakarta City, but the implementation of activities in the Teacher Working Group is part of the Continuing Professional Development which can be submitted as credit figures for promotion not yet known by stakeholders. The concept of Sustainable Professional Development which is understood is part of the submission of credit numbers.

The support of the technical implementing unit in the MakasarSubdistrict of East Jakarta City in providing legality for the implementation of Sustainable Professional Development activities in the Teacher Working Group is shown by issuing a decree on the implementation of cluster activities. Infrastructure facilities owned by the core school are not from the East Jakarta City Administrative Office, but come from the procurement of School Operational Assistance funds.

As a policy implementer at the Regional level, the East Jakarta Administrative City education office must submit policies and programs that are planned by the central government to school supervisors, principals, and teachers. Therefore, it has become an obligation for the East Jakarta Administrative City Education Office and the East Jakarta City Administrative District technical implementation unit to disseminate standard operational guidelines and procedures for the implementation of Teacher Working Groups and Subject Teacher Consultations so that the implementation of Continuous Professional Development in the Teacher Working Group can run well.

The support of the East Jakarta Administration City Education Office for financing the implementation of Sustainable Professional Development activities in the Teacher Working Group has been seen even though it is not yet maximal. the regional technical implementation unit in the sub-district of Makasar, East Jakarta Administrative City has provided financial support by providing transport funds and honorarium for school supervisors as supervisors in the Teacher Working Group. While financing support for operational implementation of the Teacher Working Group was not provided by the education office of the East Jakarta Administrative City and the technical implementation unit of the sub-district of Makasar City, East Jakarta Administrative District.

\subsubsection{Transactions}

At the transaction stage, it is divided into 2 components, namely implementation, monitoring and evaluation. In the implementation of the results of questionnaires, interviews and observations showed that the structuring and planning of the Program for the Development of Sustainable Professionalism in Teacher Working Groups was not based on the needs of teachers.

In the transaction phase the program implementation is not based on the analysis of teacher needs. The implementation of sustainable professional development programs is not working well as a result of the implementation of programs that are not based on teacher needs analysis, provision of resource persons who are not appropriate and/or inappropriate with the activity material, and weak management of the process of sustainable professional development through self development in the Teacher Working Group . Program implementation that is not based on teacher needs analysis will make the activities of sustainable professional development in the Teacher Working Group less effective. So that it does not help the teacher in solving the problems of learning in the classroom, as well as empowering and helping the teacher in carrying out the tasks of the teacher in school. Resource persons from external sources, namely supervisors made sustainable professional development activities only one direction and no mentoring between junior and senior teachers and peer-teaching. The process of implementing a sustainable professional development program is determined by the initial conditions of the strategic environment for the implementation of a sustainable professional development program. Furthermore, the implementation process of the professional development program continues to determine the results of the implementation of sustainable professional development programs.

Based on the materials that are often used in the Development of Sustainable Professionalism.In the Teacher Working Group. The material that is often taught is material in routine programs and developers. The material in the routine program that is often carried out is the preparation of Learning Implementation Plans, coupled with the material in the developer program namely classroom action research. The selection of program plans and activity material that is not based on the teacher's needs makes the Sustainable Professional Development activities less useful. Problem solving in the classroom, such as learning methodologies, learning strategies, and assessments, is not much discussed in the Development of Sustainable Professional Activities in the Teacher Working Group.

The activity material provided for the ongoing professional development activities for teachers in the Teacher Working Group is based on the program plan 
that was designed at the beginning of the school year. After the researchers evaluated the standards set in the signs and the implementation of the Teacher Working Groups and facts found in the field - showed that the material presented to the ongoing professional development activities for teachers in the Teacher Working Group was more about policy implementation.

In the context of the 2013 curriculum implementation, all Teacher Working Groups are the place for mentoring the 2013 curriculum implementation. This has an impact on changes in the Teacher Working Group's plans and program calendar in the current year. Some activities that have been planned cannot be implemented because of an unplanned program from the beginning of the school year. Program planning must also be prepared so that the results can improve the careers of their members. Like seeing the needs of its members in making scientific publications, or innovative works, the members can get a number of credit numbers. So that all activities for the Development of Sustainable Professionalism in Teacher Working Groups can be beneficial for teachers in improving their competencies and increasing their careers.

Resource persons/instructors are also an important part in the implementation of the Continuing Professional Development Program in the Teacher Working Group. Therefore, it is expected that in the implementation of the Sustainable Development Professionalism activities in the Teacher Working Group the existence of best practices among teachers, so that they can together improve learning in schools. Personnel/Instructors who are continuously from the element of school supervisors cannot help the teacher fully because those who face students directly are teachers. In addition, the existence of a variety of activity methods will make the Development of Sustainable Professional Activities in Teacher Working Groups more useful.

Financing comes entirely from the contribution of the Teacher Working Group. The absence of financial support from the East Jakarta City Education Office in the Makassar sub-district made the Teacher Working Group unable to call external sources. With the presence of external speakers, of course, can provide information on solutions in dealing with learning problems and then help the teacher in producing products that can be submitted for raising the pledge.

Infrastructure facilities already available in the core school cannot meet the needs of Sustainable Professional Development activities, for example the limited number of infocus and screen so that all participants cannot see the presentation clearly. Monitoring and evaluation is always carried out by school supervisors with assistance in the Teacher Working Group, this monitoring and external evaluation is carried out very well so that there will be input into the implementation of Sustainable Professionalism in Teacher Working Groups which has an impact on improving the quality of the Continuing
Professional Development program. Monitoring and evaluation conducted by the East Jakarta City/ District Education Office in Makassar also needs to be continued. School supervisors cannot play a dual role as coaches, resource persons and perpetrators of monitoring.

\subsubsection{Outcomes}

At the outcomes stage, the results of the implementation of sustainable professional development programs for teachers in the Teacher Working Group show that:

a. There are 5 (five) Teacher Working Groups in Makassar sub-district where all the teachers get the results of the teacher performance appraisal on average get the title "good" or get a score of 75 to 87 .

b. Less than $50 \%$ of teachers use the results of ongoing professional development for promotion.

c. 2016 shows that all 6 th grade students in elementary schools in Makassar sub-district pass the school exam.

d. Approximately $54 \%$ of teachers in Makassar sub-district do not have an educator certificate.

\subsection{Discussion}

The discussion of research results is divided into 3 stages, namely anteceden transactions, and outcomes.

\subsubsection{Antecedent}

The findings at the antecedent stage indicate that the absence of contingency between the criteria set by (intended) with the findings in the field (Observation). Based on the evaluation criteria for program implementation, the results of the evaluation study on the antecedent stage showed a moderate level of effectiveness. This is indicated by several aspects that have met the criteria achieved including understanding of legality, and the existence of Sustainable Professional Development, Vision Mission and Objectives for Developing Sustainable Professionalism in the Teacher Working Group, concepts and objectives of Sustainable Professional Development, and infrastructure. Whereas for socialization, financing, membership of the Teacher Working Group, and resource persons /instructors have not met the criteria set.

Based on the evaluation criteria in the antecedent stage, it shows that the regional government, namely the Education Office in the District of Makassar, East Jakarta Administration, has not fully supported the implementation of Sustainable Professional Development for teachers, this is indicated by the amount of financial and non-financial assistance and support such as resource persons and facilitators. This is supported by the results of research conducted by USAID that almost all Teacher Working Groups are not going well because of management problems and lack of support from local governments (2009). This shows that the effectiveness at the antecedents stage is in the moderate category which still has to be improved because the evaluation results at this stage have a contingency with the implementation of 
Sustainable Professional Development in the transaction and outcomes stages.

\subsubsection{Transactions}

The process of implementing the Continuing Professional Development Program Contingency with the initial conditions of the implementation of the Continuing Professional Development Program. Furthermore, the process of implementing the Continuing Professional Development Program has a contingency with the results of the implementation of the Sustainable Professional Development Program.

The findings at the transaction stage indicate that the lack of contingency between the criteria that have been established (intended) and the findings in the field (observation). At the transaction stage, the program evaluation is focused on the criteria for evaluating effectiveness, efficiency and adequacy. The effectiveness of the implementation process of the Sustainable Professional Development Program is in the category of median and tends to be low as a result of program planning that has not been based on the analysis of teacher needs, provision of resource persons who are not appropriate and/or inappropriate with the material of activity, and weak management of the process of implementing Sustainable Professional Development through development yourself in the Teacher Working Group. Through self-development in the Teacher Working Group. Program planning that is not based on teacher needs analysis will make the Development of Sustainable Professional Activities in Teacher Working Groups less effective. So it does not help the teacher in solving the problems of learning in the classroom, as well as empowering and helping the teacher in carrying out the tasks of the teacher in school. External speakers, namely supervisors, made Sustainable Professional Development activities only one direction and there was no mentoring between junior teachers and senior teachers as well as perteaching.

Based on Isac and Wiliam (1982) Efficiency is related to the amount of effort needed to produce a certain level of effectiveness. In the transaction phase, the implementation of the Sustainable Professional Development Program is not yet efficient. This is indicated by the fact that the calendar of activities prepared cannot be fully implemented, then the frequency of meetings that are still below the criteria is that the minimum number of meetings in 1 year is 12 months. The calendar of activities arranged is not in accordance with the implementation, because of the many agendas in the school so that the Development of Continuing Professionalism in the Teacher Working Group cannot run well.

Furthermore, the evaluation criteria for the transaction stage are adequacy. Adequacy in public policy can be said that the goals that have been achieved have been felt sufficient in various ways Farida (2008) At this stage, adequacy concerns how far a level of effectiveness satisfies the needs, values, or skills that create problems. Based on the results of planning research at the transaction stage, it has not been able to support the implementation of Sustainable Professional Development, programs that are not based on general programs, core programs and supporting programs in accordance with the guidelines for the implementation of the Teacher Working Group. This was supported by USAID's research that some deficiencies in the implementation of activities in the Teacher Working Group included, among others, effectiveness in improving teacher competencies, lack of qualified resource persons, lack of coordination, lack of assessment tests in developing programs, and absence of follow-up from instructor or resource person.

Resource persons/instructors are also an important part in the implementation of the Continuing Professional Program in the Teacher Working Group. The expected results with the Development of Sustainable Professionalism activities in the Teacher Working Group include giving teachers the opportunity to share experiences and provide mutual assistance and feedback; increase knowledge, skills and attitudes and adopt innovative learning approaches for teachers; empower and assist teachers in carrying out teacher duties in schools in order to improve learning in accordance with standards; developing mentoring activities from senior teacher to junior teachers Therefore, it is expected that in the implementation of the Sustainable Development Professional Activities in the Teacher Working Group the existence of best practices between teachers, so that they can jointly improve learning in schools. Personnel/ instructors who are constantly from the school supervisor cannot help the teacher fully because the students who face them directly are teachers. In addition, the existence of a variety of activity methods will make the Development of Sustainable Professional Activities in Teacher Working Groups more useful. Financing comes entirely from the contribution of the Teacher Working Group. The absence of financial support from the East Jakarta Education Office/technical implementation unit in the MakasarSubdistrict area makes the Teacher Working Group unable to call external sources, of course, can provide information on solutions to learning problems. Then help the teacher in producing products that can be submitted for promotion.

Infrastructure facilities already available in the core school cannot meet the needs of Sustainable Professional Development activities, for example the limited number of infocus and screen so that all participants cannot see the presentation clearly. Monitoring and evaluation are always carried out by school supervisors. With assistance in the Teacher Working Group, external monitoring and evaluation is carried out. This is very good so that there will be input into the implementation of Sustainable Professionalism in the Teacher Working Group which has an impact on improving the quality of the Continuing Professional Development Program. Monitoring and 
evaluation conducted by the East Jakarta City Education Office/technical implementation unit in the Makassar District sub-district also needs to be continued. School supervisors cannot play a dual role as coaches, resource persons and perpetrators of monitoring.

\subsubsection{Outcomes}

The findings at this stage indicate that there is a contingency between the criteria that have been established (Intended) and findings in the field (Observation). So that the effectiveness of the achievement of the results of the implementation of the Sustainable Professional Development Program in the Teacher Working Group is in the category of moderate high-income groups. The results of the implementation of the Sustainable Professional Development Program through self-development in the Teacher Working Group are the estuary of the effectiveness of the strategic components of the initial environmental conditions and the components of the process of implementing the Sustainable Professional Development Program. The higher the effectiveness of the aspects contained in the initial condition and process components, the higher the effectiveness of the results that can be achieved, and vice versa, the lower the effectiveness of the aspects contained in the initial condition and process components, the lower the effectiveness of results that can achieved. This is supported by research conducted by USAID that almost all teachers who participated in activities in the Teacher Working Group implemented the new methodology they learned in the Development of Sustainable Professionals

a. Outcomes phase, (period or period after the program is implemented where data is collected);

1. Description

This description includes; (1) intense (what is the desired or predicted result); and (2) observation, (data collected at the end of the program can be in the form of test scores and scores).

2. Judgments

Consists of; (1) standard (criteria used as a basis for comparison); (2) judgment (the process of comparing intents, observations with standards).

According to Stake (2004) when evaluators are considering educational programs, they inevitably have to do two comparisons, namely: comparing the conditions of the results of certain program evaluations with those that occur in other programs, with the same target object; compare the conditions of the results of the program implementation with the standards intended for the program concerned, based on the objectives to be achieved.

\section{CONCLUSION}

Based on the results of the evaluation of the ongoing professional development program, it can be concluded that the implementation of a sustainable professional development program has not run effectively and efficiently. The criteria for evaluation of adequacy and accuracy of program implementation are still minimal. Several components in the implementation of the program have not been congruency between the expected goals (intended) and the actual facts of the facts (observation). Possibly the contingency between antecedent, transaction, and outcomes shows that the linkages between the effectiveness of program implementation at antecedent stages have a contingency with the stages of transactions and also on outcomes.conclusion of the results of this study as follows:

The antecedent phase, the implementation of a sustainable professional development program in the Teacher Working Group most of the criteria evaluated supported the implementation of the program but was still hampered by the support of the technical implementing unit of the Makassar sub-district, especially in the dissemination of operational guidelines and operational standards for the implementation of the Teacher Working Group and Teacher Consultation Subjects, financing, and providing resources. The initial conditions of the strategic environment for the implementation of self-development activities in the Teacher Working Group have a contingency with the process and results of the implementation of a sustainable professional development program for teachers. The initial conditions of the strategic and supportive environment are the conditions required in the implementation of a sustainable professional development program so that it becomes a determining component of the effectiveness of the process and the results of a sustainable professional development program in the Teacher Working Group.

Transactions, the implementation of a sustainable professional development program is not working well as a result of program planning which is not based on the analysis of teacher needs, providing speakers who are not appropriate and/or inappropriate with the material activities, and weak management of the process of sustainable professional development implementation through self-development in the Group Teacher's work. Program planning that is not based on teacher needs analysis will make sustainable professional development activities in the Teacher Working Group less effective. So that it does not help the teacher in solving the problems of learning in the classroom, as well as empowering and helping the teacher in carrying out the tasks of the teacher in school. Resource persons from external sources, namely supervisors made sustainable professional development activities only one direction and no mentoring between junior and senior teachers and peer-teaching. The process of implementing a sustainable professional development program is determined by the initial conditions of the strategic environment for the implementation of a sustainable professional development program. Furthermore, the implementation process of the professional development program continues to determine the results of the implementation of sustainable 
professional development programs.

Outcomes; the implementation of a sustainable professional development program in the Teacher Working Group has been well implemented. The results of the program implementation are determined by the initial conditions of the strategic environment for the implementation of a sustainable professional development program and the implementation of a successful professional development program. The results of the implementation of sustainable professional development programs for teachers in the Teacher Working Group indicate that the Development of Sustainable Professionalism has an impact on teacher performance indicated by the average results of the teacher performance appraisal getting the title "Good or getting a score of 78 to 92 then in 2016 shows that all students Grade 6 in elementary school in Makassar districtpassed the school exam. However, less than $50 \%$ of teachers use the results of Sustainable Professional Development products in the form of scientific publications and innovative works for promotion.

\section{REFERENCES}

Alkin, Marvin C. (2011). Evaluation essentials: from A to $Z$. New York: The Guilford Press.

Suharsimi A.. Cepi, Safrudin. Evaluasi Program Pendidikan. Jakarta; Bumi Aksara, 2010 Babita Arora. Research Article Continuous Professional Development For Effective School Improvement. International Journal of Advanced Research (2016), Volume 4, Issue 3, 295-298. ISSN 2320-5407.

Al Yahya, Mohammed Saad dan Norsiah BM. (2011) Evaluation of Effectiveness of Training and Development: The Kirkpatrick Model. www.ajbms.org Asian Journal of Business and Management Sciences ISSN: 2047-2528 Vol. 2 No. 11 (14-24). Robert E. Stake, Program Evaluation Particularly Responsive Evaluation (Journal of Multi Discilkinary Evaluation, Volume 7, Number15 ISSN 1556-8180).

A Whohab Khan .(2010), Associate Professor, Department of Surgery, BSMMU, Continuing Professional Development (CPD); What should we do?. Bangladesh Journal of Medical Education, Vol.- 01, No.-01

A Yumiko O. and Johanna F, (2010). A case study of continuing teacher professional development through lesson study in South Africa (South African Journal ofEducation. EASA Vol 30: 59 - 74.

Diah Widuri. (2013). The Influence of Direct Service Program Quality Assistance Funds and Routine Meetings on Improving Teacher Performance in Teacher Working Groups in ParigiMoutong District.e-Jurnal Katalogis, ISSN: 2302-2019, Volume I Number 2, April Minae I. Mwangi, and David Khatete, Teacher Professional Development
Needs For Pedagogical ICT Integration In Kenya: Lessons For Transformation (European Journal of Education Studies ISSN: 2501 - 1111 ISSN-L: 2501 1111 Available on-line at: www.oapub.org/edu).

Linda E.. (2012). What is Teacher Develipment. Oxford review of education, Vol 28, No. 21.

Goodall, Janet, Cristoper D., etc. (2005) Evaluating the Impact of continuing Professional development. Research report. The University of Warwick.

Issac, Stepen and William B. Michael, (1982). Handbook in Research and Evaluation $2^{\text {nd }}$ edition, san Diego california: Edits Publisher.

Kennedy, Aileen. (2005). Models of continuing professional development: a framework for analysis. Jhournal of in - service Education, 31 (2).

OECD. (2009). Creating effective Teaching and Learning Environment First result form Teaching and Learning International Survey.

Reynolds. (2007) Teachers' Continuing Professional development: A New Approach. International congress for Effectiviness and improvement.

Stake, Robert E., (2004). Standad-Based \& Responsive Evaluation, Thousands Oaks-London-New Delhi: Sage Publications.

Tayibnapis, Farida Y., (2008). Evaluasi program dan Instrumen Evaluasi untuk program pendidikan dan penelitian, jakarta: Rineka Cipta.

USAID. (2009). Teacher education and Profesional development in indonesia: A Gap analysis . (Jakarta: United States Agency for International Devolepment, 2009 . 